Meta

Journal des traducteurs

Translators' Journal

\title{
Better than the Original: Humorous Translations that Succeed
}

\section{Don L. F. Nilsen}

Volume 34, numéro 1, mars 1989

Humour et traduction

Humour and Translation

URI : https://id.erudit.org/iderudit/003737ar

DOI : https://doi.org/10.7202/003737ar

Aller au sommaire du numéro

Éditeur(s)

Les Presses de l'Université de Montréal

ISSN

0026-0452 (imprimé)

1492-1421 (numérique)

Découvrir la revue

Citer cet article

Nilsen, D. L. F. (1989). Better than the Original: Humorous Translations that Succeed. Meta, 34(1), 112-124. https://doi.org/10.7202/003737ar d'utilisation que vous pouvez consulter en ligne.

https://apropos.erudit.org/fr/usagers/politique-dutilisation/ 


\section{BETTER THAN THE ORIGINAL : HUMOROUS TRANSLATIONS THAT SUCCEED}

DON L. F. NILSEN

Arizona State University, Tempe, Arizona

\section{INTRODUCTION}

In Semantic Theory, Kurt Baldinger said,

By all the accepted theories of linguistics, it should be impossible to translate from one language to another. Fortunately the ordinary translator does not know this, and he goes ahead and translates anyhow. (242)

\section{PHONOLOGICAL CONSIDERATIONS}

Words in one language often sound the same as words in another language. Dennis Preston asks the question, "How do you kill a Polish herring?" and then he answers the question, "With a sledge hammer". This makes sense only to a person who knows that the Polish word for herring is "shledzh".

In Arizona, there is a widespread jokelore dealing with humorous translations from Spanish into English. James S. Griffith, Director of the Southwest Folklore Center at the University of Arizona has indicated that there are commonly known ones, such as the birthday song that Anglos sing which starts off "Zapo Verde to You". Richard Morales of Tucson tells a humorous anecdote about his uncle who was interpreting for several friends and associates on the occasion of their being inducted into the army in World War II. "What's the man's name?" said the Anglo sergeant. "Casimiro Guerra" responded Richard's uncle. "What does it mean ?" asked the sergeant. Desperate to please, Richard's uncle translated the name literally as "Near See War". Griffith also points out that in the Southwest there are also translation riddles, such as the following: "If a Tea Cup is a cup that people drink Tea out of, what is a P-cup?" The answer is given in Spanish - "una camioneta Mexicana" (a Mexican truck) (123). There are also knock knock jokes :

"Knock, knock."

"Who's there?"

"Kelly."

"Kelly Who?"

"Kelly (Que le) importa?" (What does it matter?") (123)

There is even a toast :

Here's to Dear Old Mexico, where the Sopa's not Soap, and the ropa's not rope and the butter's meant to kill ya. (123)

Sopa is the Spanish word for "soup", not "soap". And ropa is the Spanish word for "clothing", not "rope". And the Spanish word for "butter" is "mantequilla". This toast plays not only on the embarrassment of using false cognates, but also on the ancient stereotype of unsanitary food in Mexico (123). 
English also contains some words that are very confusing for Yiddish speakers. In a chapter on vocabulary learning in Leonard Q. Ross's The Education of $H^{*} Y^{*} M^{*} A^{*} N$ $K^{*} A^{*} P * L^{*} A^{*} N(33-42)$, Hyman Kaplan is given the items heaven, pitcher, fascinate, and university to put into sentences. These were the results:

In sommer, ve all heaven a fine time.

Plizz take milk from de pitcher. Fine! De pitcher hengs cockeye! Also fine! Pitcher.. pitcher.

In India is all kinds snake-fescinators.

Elaven yiss is married mine wife an' minsalf, so is commink for our tvalft univoisity. (33-42)

Another student in the same ESL-class was asked to use enamel. She said, "Enamel is used for painting chairs", to which Mr. Kaplan responds, "Mistake by Milnick! Ha!" "Mit enimals she is painting chairs?"

Whether the words are accidentally similar (as above), or systematically similar, as cognates, such words often bring a smile when they are translated. Winfred Lehmann points out that the syllable structure of Japanese combines with the unique inventory of Japanese phonemes to give a comical ring to certain borrowings from English. "Baseball" in Japanese becomes "baasaburro"; "bull pen" becomes "buru-pen"; "home run" is "hoomu-ran"; and most interesting of all these baseball terms is "strike" which goes from a single syllable to five syllables in Japanese "sutoraiku" (375).

Just as there is humor in translating cognates, there is also humor in translating false cognates. In Spanish, "duchar" means "to shower"; "molestar" means "to bother"; "tuna" in Spanish is a prickly pear; "groceria" is a vulgarity; "constipado" can mean having a stuffed-up nose; and "embarazada" can mean pregnant. Russell Baker gives a tongue-in-cheek account of an example of a false cognate from German:

Of all foreign tongues, German is the easiest for an English speaker to master. This is because so much of English comes almost unchanged from German. Take the German word "Herr", for example. At first glance you may think it means "her". Upon hearing it pronounced properly, however, you will instantly realize that "Herr" is the German word for "hair". (A7)

\section{Baker continues :}

Thus Adolf Hitler was often referred to as "Herr Hitler" - in English, "Hair Hitler" because of his curious mustache and the swath of lank hair that was plastered down over his forehead. If Hitler had been bald he would have been called "Herrless Hilter". (A7)

Similar to the false cognate is the loan translation, where the metaphor is borrowed from one language to another. This is another area of potential translation humor - both intentional and unintentional. Consider some examples from Canadian French: "chien chaud" (hot dog), "brassières de sauvetage" (life jackets), "Dames" (Ladies' Restroom), "liqueur" (soft drink). In all of these cases the translated metaphor almost works, but not quite, and it is this slight disparity which causes us to smile (Nilsen, "Bilingual": 134).

There are three humorous translation parodies of nursery rhymes, which are totally phonological in nature. Orthography, morphology, syntax, semantics, and pragmatics are totally ignored in order to do "homonoid" translations. I have coined the term "homonoid" to describe words which are almost homonyms, but not quite, especially when these "homonyms" occur in different languages. All three books have English as the source language. Two of the three have French as the target language (Mots d'Heures; 
Gousses, Rames, by Luis d'Antin van Rooten, and N'Heures Souris Rames by Ormonde de Kay). The other book is in fake German (Mörder Guss Reims by John Hulme). I shall give one example from each of the three books:

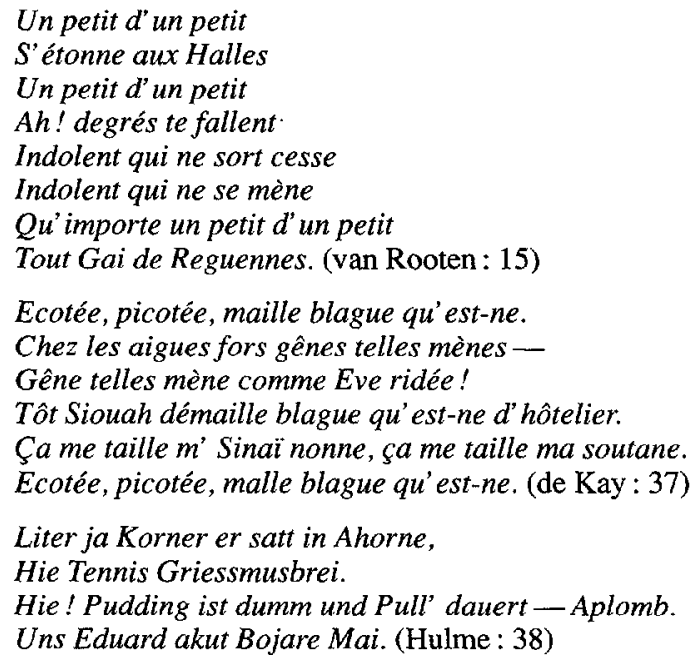

In the three representative samples above, the grammar and sense of the target language are mutilated. It is one level worse than a word-for-word translation, for it is a sound-for-sound translation. But since it is a parody, worse becomes better. There is enough sense, and enough grammar in the translation to confuse the unsophisticated reader into thinking that it is a legitimate piece. Only if he listens to the sounds, and disengages from the grammar and the sense will he be able to make the connection to the original nursery rhymes. Once this is done, he recognizes it as a translation, as a parody, and as humor.

In informal French, the expression "chouette" means not only "owl", but also "right on!" Therefore, some French teenagers wear T-shirts with a picture of an owl on them and on the T-shirt is written a message which is bilingually translatable in either direction, "Chouette Shirt".

Translation errors are also very humorous, especially when a phonological error can result in some sort of semantic reformulation. Consider the following possible errors for Spanish speakers learning English:

This is a berry good milkshake.

They were feeding father to the cows.

I saw three sheeps come sailing by.

My favorite collar is jello. (or I'm studying law at Jail.)

Now that she had new glasses she was better able to wash the children.

I mate him more than once. (Nilsen, "Bilingual": 129)

Translation across dialects is also sometimes humorous. A speaker of standard English meets a person from Brooklyn in a park. The Brooklynite speaks first, "Chees, look at da boids". The standard speaker responds. "Those aren't boids; they're birds", to which the Brooklynite responds with "Dat's funny, dey choip like boids". Humor happens across prestige dialects as well. Consider the story about an American in a British hospital. He asks the British nurse, "Did I come here to die ?" "No", responds the nurse, "it 
was yesterdie". Or consider the translation problem when an American asks a Britisher what he does. The Britisher, in his $r$-less vowel-changing dialect responds "I'm a clerk". The American assumes on the basis of this answer that the Britisher sits around all day going "tick tock tick tock".

\section{ORTHOGRAPHIC CONSIDERATIONS}

There is a story about a Mexican who went into an American department store needing a pair of stockings. Since he didn't know English, he tried to pantomine his request to the clerk, but he was unsuccessful on attempt after attempt. Finally, the clerk, after having tried everything else, held up a pair of stockings, and the Mexican said, "Eso si que es". The American was amazed by this statement, which he perceived as "S.O.C.K.S.", and declared that they could have saved a lot of time if the Mexican had merely spelled the item sooner.

Sometimes translation from one dialect to another can be as confusing as that from one language to another, especially if the original is written in an illegible pen. In Roughing It, Mark Twain had a particularly difficult problem to solve, so he wrote Horace Greeley for help. Greeley sent him a letter that Twain made five different attempts to translate. The first word, for example, changed from "polygamy" to "Bolivia" to "poultices" to "potations" to "potatoes". By the time he had translated the letter, he no longer needed the advice (Nilsen, "Twain": 68).

Another device which often causes humor in the translation process is the bilingual heteronym. Monolingual (English) heteronyms are words like "wind, bow, read, lead, tear", etc., all of which have two different pronunciations, and two different meanings in English. The bilingual heteronym is a bit more sophisticated, and therefore a bit more effective as a device of language play. "Mince" in French means slender; in English (with a different pronunciation) it means to chop into very fine pieces. "Court" in French means short; in English it means to woo. "Sang" in French is blood, but in English it is the past tense of "sing". "Chat" in French is a cat ; in English it refers to a very informal conversation, and the same process goes on for "lame, coin, chose, tire, singe, dent, rue" and so on (Nilsen, "Bilingual": 132).

\section{MORPHOLOGICAL AND SYNTACTIC CONSIDERATIONS}

If we develop an awareness of the morphology of various languages, we can have many insights as words travel from one language to another, and many of these insights are epiphanal in nature. That is, what was originally mundane has now become fascinating, because we know so much more about the word than we had known previously. The English word "levee" come from Cajun French. In French, this word is the past participial form of the verb "lever" meaning "to raise or elevate". "Hoosegow" and "pinto" come from Spanish "juzgado" (judged), and "pintado" (painted) respectively. Some English words which were originally Spanish past participial forms are not so disguised - "tornado", "tostado", "enchilada", "desparado", etc. English "hacienda" is a present participial form of the Spanish verb "hacer" (to make or do). "Yankee" and "poppycock" are from Dutch words meaning "John Cheese", and "soft dung" respectively. And "Islam" and "Muslim" are variants of the same Arabic word meaning "peace". A related Hebrew word is "shalom". The suffix -er in German is attached to a word to designate a place of origin. That was the original meaning in such words as "frankfurter", "hamburger", and "wiener" (something from Frankfurt, Hamburg, and Vienna (Wien) respectively), but because these meanings have been so greatly altered after they were borrowed into English, translations have been affected. 
Marie-Thérèse Blanc wanted to popularize American literature in her native France, so she translated Mark Twain's The Jumping Frog of Calaveras County into French. Twain later saw the translation and translated it back into English. The result was not a translation, but was a parody of a translation, "It there was one time here an individual known under the name of Jim Smiley; it was in the winter of ' 49 , possibly well at the spring of '50, I no me recollect not exactly" (Nilsen, "Twain": 68).

The language which most frustrated Mark Twain was German. In A Tramp Abroad, he said that after devoting "nine full weeks" to the study of German, he had decided to suggest certain revisions. "Leave out the Dative Case" because "it confuses the plurals, move the verb further up front, import some swear words, and [either] do away with those great long compounded words, or [else] require the speaker to deliver them in sections, with intermissions for refreshments". He further suggested that the Germans should "retain Zug and Schlag and discard the rest of the vocabulary". He said that if these changes are not made, German "ought to be gently and reverently set aside among the dead languages, for only the dead have time to learn it" (Nilsen, "Twain": 68).

In A Tramp Abroad, Twain illustrates one of the great long compounded words that occurs in German, by giving an English translation that is true to German morphology and syntax: "In the daybefore yesterdayshortlyaftereleveno'clock Night, the inthistownstandingtavern called 'The Wagoner' was downburnt" (Twain: 259). In this same book Twain said that there are more adjectives in German than there are black cats in Switzerland, and they are all elaborately declined. In order to demonstrate how elaborate and difficult the declensions are, Twain said that he had heard of a California student in Heidelberg say that he would rather decline two drinks than one German adjective.

German has grammatical while English has natural gender. Here again, Twain's observations are humorous, as he indicates that in German a young lady has no sex, while a turnip is feminine. Twain considers this to be overwrought reverence for the turnip, and callous disrespect for the girl.

\section{SEMANTIC AND PARAPHRASTIC CONSIDERATIONS}

At the beginning of this article we saw how it was possible to translate the surface structure (phonology) while totally disregarding the deep structure (meaning) when we investigated N'Heures Souris Rames, etc. It is also possible to reverse this process, translating the deep structure (meaning) while totally disregarding the surface structure (phonology). And the effect is very similar. Gershon Legman tells a story about an Englishman who is about to return home from America and who asks for a typical American joke he can repeat in England. He is given the following riddle:

A girl is standing on a street corner and three men go by, one on a horse, one on a bicycle, and one on foot. One of the men knows the girl. Which one? "I give up," says the Englishman: "which one?" "The horse-manure !" (179)

When the Englishman returned home to England he tried his best to remember all of the details of the joke, and the following resulted:

A young lady is standing at an intersection - this is in America, you know - and three gentlemen pass by : an equestrian, a pedestrian, and a velocipedist. One of them is acquainted with the young lady. Now which one ?" "We give up, Reggie, Which ?" "Well, I don't know how that American chap did it, but the answer is 'horseshit'?" (179)

Every weekend I play tennis with Isabel Schon, a bilingual speaker of Spanish and English. At one point I had lost track of the score, so I asked Isabel. Knowing that I also 
spoke some Spanish, she responded that the score was "without elbows", a message that makes absolutely no sense until it is translated into Spanish. "Without elbows" would be translated into Spanish as "Sin codos". Then through the process of metanalysis, she expected me to break the word after the second syllable rather than after the first, and the result was "cinco dos" - "five to two".

Leo Rosten tells a similar story, but Rosten's story is true - however, I suspect with a little embellishment. In a 1966 article in Look entitled "Wallop Yon Horse with a Parachute", Rosten says that a simple English sentence like "I want my meat well done", when uttered by a Sicilian might come out as "I want my mate walled in". Later in the article Rosten explains the title of his article. He was trying to say "I want one umbrella and a pair of man's gloves", in Spanish, but he got paraguas "umbrella" confused with paracaidas "parachute". And he confused caballo "horse" with caballero "gentleman". And finally he said guantada "a wallop" instead of guante "a glove". So rather than asking for an umbrella and a pair of man's gloves, he told the clerk in effect to "give a wallp to a horse with a parachute" (16).

In A Tramp Abroad, Mark Twain indicates that a word may be much stronger in one language than another. His example comes from German: "Observe the strongest of the several German equivalents for explosion - Ausbruch. Our word Toothbrush is more powerful than that" (Twain : 260).

The relationship between words and meanings is sometimes arbitrary, and sometimes not arbitrary, and this fact has an important effect on translation. Consider the story about an American, a Mexican, a Frenchman, and a German all arguing with each other about which of their languages is best. The American brought up the word "butterfly". "Isn't that a beautiful and appropriate word", he said. "Itsounds just like what it represents, the soft fluttering of gentle wings". The Mexican said that he felt that the Spanish word was just as sound-symbolic - "mariposa". The Frenchman felt that "papillon" was even better than that English or Spanish word for representing this soft fluttering sound. At this point, the German entered the conversation, "So was ist wrong mit 'Schmeterlung'?"'

In Innocents Abroad, Twain tells of some of the translation problems he had encountered in Europe. As he translated from English to French, in order to make himself understood to the French, the result was delightful, "Monsieur le Landlord - Sir: Pourquoi don't you mettez some savon in your bedchambers?" In the same novel he tells of a French guide who says in English with a strong French accent: "If ze zhentlemans will to me make ze grande honneur to me retain in hees serveece, I shall show to him every sing zat is magnifique to look upon in ze beautiful Paree. I speaky ze Angleesh pairfaitemaw" (Nilsen, "Twain": 68).

In this same novel Twain also commented on the Italian language. "They spell it Vinci and pronounce it Vinchy." He then adds, "Foreigners always spell better than they pronounce". He describes a "notish" with an Italian accent: "This hotel which the best it is in Italy and most superb is handsome locate on the best situation of the lake..."

Willard Espy tells about some of the humorous results of translation in his Children's Almanac of Words at Play.

A Russian heard someone say, "The child was suspended for misconduct", and was shocked; the literal translation into Russian came out "The child was hanged for juvenile delinquency". Another time, a Russian tried to explain to an American girl that when he gazed on her lovely face time stood still; but what he actually said was, "You have a face that stops the clock". (121) 
Espy continues by telling about a World War II incident.

A Soviet diplomat complained to an American official that Washington was "behind" in delivering planes and tanks to Moscow. The American replied it was because Moscow was "behind" in letting us know what weapons they needed. "I have not come here", said the

Russian, "to discuss my behind, but your behind". (121)

Going from one dialect to another, meaning can be either lost or gained in the translation. Stuart Chase tells about a New York plumber who wrote to Washington saying that he had found hydrochloric acid excellent for cleaning drains, and he asked the Washington office whether or not it was harmless. Washington responded, "The efficacy of hydrochloric acid is indisputable, but the chlorine residue is incompatible with metallic permanence". The plumber wrote back that he was very glad that someone agreed with him, and Washington replied with a note of alarm: "We cannot assume responsibility for the production of toxic and noxious residues with hydrochloric acid, and suggest that you use an alternate procedure". Again the plumber wrote that he was happy to learn that they [Washington] still agreed with him. At this point, Washington translated their message into common everyday understandable prose: "Don't use hydrochloric acid; it eats hell out of the pipes!" (Eschholz: 46).

As the above anecdote illustrates, translating from one level of formality to another can have a profound impact on the message. Notice the different connotative effects resulting from the following sentences communicating roughly the same message, but at a different level of formality:

STANDARD: Sir, you speak English well.

DIALECT : Cousin, y'all talk mighty fine.

ACCENT: Paisano, you speak good the English.

COLLOQUIALISM: Friend you talk plain and hit the nail right on the head.

CANT/ARGOT : Duchess, let's have a bowl of chalk

JARGON : You are free of anxieties related to interpersonal communication. (Flexner: vi-viii)

In an article entitled "Lost in Translation", Richard Lederer points out that John F. Kennedy made an important translation blunder in 1963 when he gave an impassioned speech at the Berlin Wall. What he wanted to say was, "Ich bin Berliner!" meaning "I am a Berliner!" since in German words for nationalities are not preceded by articles. What Kennedy actually said was, "Ich bin ein Berliner!" - "I am a jelly doughnut" (40). Lederer also gives a number of interesting English signs he has seen during his international travels, signs like,

IN A LEIPZIG ELEVATOR : "Do not enter the lift backwards, and only when lit up."

IN A BELGRADE ELEVATOR: "To move the cabin, push button for wishing floor. If the cabin should enter more persons, each one should press number of wishing floor. Driving is then going alphabetically by national order."

OUTSIDE A HONG KONG TAILOR SHOP : "Ladies may have a fit upstairs."

IN A BANGKOK DRY CLEANERS : "Drop your trousers here for best results."

IN A RHODES TAILOR SHOP : "Order your summer suit. Because is big rush we will execute customers in strict rotation."

IN AN ADVERTISEMENT BY A HONG KONG DENTIST : "Teeth extracted by the latest Methodists."

IN THE BROCHURE OF A CAR RENTAL FIRM IN TOKYO: "When passenger of foot heave in sight, tootle the horn. Trumpet him melodiously at first, but if he still obstacles your passage then tootle him with vigor." (40) 
Lederer's translated signs were similar to those we found in Afghanistan when we lived there for two years :

ON A PAINT STORE: "ITAFAQ PAINT SALER"

ON ANOTHER PAINT STORE : "KANDAHARP AINT HOUS"

ON A PLUMBER'S SHOP: "L. T. MINAN PLUMBING AND PIPING"

ON A BEAUTY PARLOR : "LADIES BEAUTY SALOON"

ON A FLOWER SHOP: "FLOWER AND BUCKET MAKER" (We assume that what is meant here is "BOUQUET")

ON A BARBER SHOP : "BARBARISM". ("Kabul”" :150-153)

In translations from English to Dari (Afghan Persian), many dead metaphors come to life. Consider the following:

DARI WORD:
xaarposhtak
xargosh
zardaaluw
sangposht
filmorgh
chaharmaghs

LITERAL ENGLISH MEANING : little thorn back donkey ears yellow plums rock back elephant chicken four brains

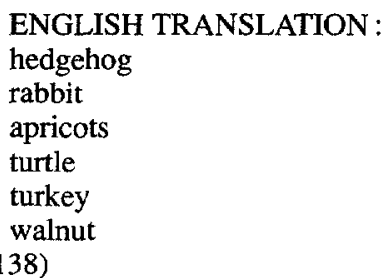

In an article entitled "Some Metaphors in Kabul Dari", Nilsen and Kamal have demonstrated that in Dari, the word lab can be used not only to refer to the lip of a person or of a cup or of a saucer (as in English) but Dari also has the lip (bank) of a stream, the lip (brim) of a hat, the lip (shoulder) of a road, and the lip (beach) of an ocean. The Dari word for "mother-in-law" is maadereshowhar, and the Dari word for tongue is zabaan. This sets up a very interesting metaphor in the Dari name for the prickly-pear cactus zabaanemaadereshowhar "mother-in-law's tongue".

In a paper entitled, "Persian Metaphorical Language", Pam Watts has indicated that if a situation is complicated in Iran it is "oza esh keshmeshiy" _- "like raisins stuck together". If something is difficult "galim as ab birun keshidan" _ "the rug is being pulled out of the water", and if someone is being blamed for everything it is "divar $e$ harchi mostarabe ruy a sareman kharab kardi" - "you drop the wall of every bathroom on my head" (1).

Japanese has some equally interesting metaphors. In Japanese there are, for example, a lot of metaphors relating to "butts", "shiri ni ha o kakeru" means literally to "hand a sail on one's butt", and it is used as an expression to "spur someone on". The Japanese phrase "shiri ga kire tonba" (a dragon fly with its butt cut off) could be used any time a job is left only half-finished (Sommer-Sawai : 14-15).

German metaphors are also fascinating for the translator. If people are tough, they are said to Haare auf den Zänen haben, "have hairs on the teeth". If they have big plans they Rosinen im Kopf haben, "have raisins in the head". Quotation marks are called Gänselfüsschen "little goosefeet" in German. These metaphors are all fresh when English speakers are the targets of the translation. English dead metaphors are equally fresh when German speakers are the targets of the translation. In English we have both $a$ budding genius and a blooming idiot. We also have metaphors like footnotes and headlines, and bottleneck and traffic jam. Some German dead metaphors are especially interesting when compared and contrasted with English dead metaphors. 
In English people make a mountain out of a molehill; in German aus einer Mücke einen Elefanten "an elephant out of a gnat". In English people can refer to a bookworm, while in German a similar person is referred to as a Leseratte "read-rat". If something bugs an English speaker it would worm a German speaker - "Es wormt mich". (Nilsen, "Bilingual": 134)

Let us contrast some dead metaphors in English and Spanish.

In English the expression barley beards occurs; in Spanish the same metaphor, barba, is used to refer to a comet. English speakers talk about having a deadline. In Spanish a speed trap is called a soldado muerto "dead soldier". In English there is an egghead. In Spanish a person's fingertip is called yema, "yolk". If an American looses a fight he cries uncle. Spanish cufflinks are called gemelos "twins". (Nilsen, "Bilingual": 130)

Translators must be very cautious when translating metaphors, especially if these metaphors are at least partially compatible in the source and the target language. Spanish speakers can refer to a crippled table. This is nothing more than the extension of a metaphor, for in both Spanish and English tables have legs. The French speaker will refer to a foot of lettuce, while an English speaker will refer to a head of lettuce. In both cases there is a metaphorical extension from a part of the human being. When a Korean refers to a key person as an egg yoke, it should be remembered that English has a similar metaphor - egg head.

Product names must be carefully chosen to avoid problems (often humorous problems) in translation. Reinhold Aman has indicated that some Americans and Europeans won't buy a Volvo because the name reminds them of a word they consider "dirty" (Dennison: 11). Liebfraumilch has similar connotations through the process of translation, and the Chevrolet Nova is translated into Spanish as "It doesn't run". Consider also the Rolls Royce "Silver Mist". In German the word "Mist" means "manure".

Connotations change from language to language for personal names too. Horace Perry Jones gives tongue-in-cheek advice on how to help English speakers remember certain Russian names:

The new Russian minister of the United States is called Somanosoff (saw my nose off). An attache of the same legation at Washington is Blowmanosoff (blow my nose off). Besides this we have Colonel Kutmanosoff (cut my nose off), of the Imperial Guard, Marshall Polmanosoff (pull my nose off), General Nozbegan (nose be gone) and many others. The Charlotte, North Carolina WHIG simply suggested: "To make a Russian name - imitate the "tchug" of a bull-frog, give one sneeze, and say "ski". (173)

The dead metaphors in names also often come to life through translation. Joe Green, John S. Brooks, Broad Shoulders, and King Swollen Foot are nothing more nor less than literal translations of Giuseppe Verdi, Johann Sebastian Bach, Plato, and Oedipus Rex. Names translate in strange ways from one language to another because they have both a surface structure and a deep structure realization. "Louis Cinq" in French becomes "Louie Sank" in English. In Recognitions, William Gaddis presents a twolanguage pronunciation pun when the protagonist refers to the joke about the five Jones brothers. "Have you heard that? Los cinco-Jones ?" In Spanish the more likely translation of this is not "five Jones", but "without balls" — "sin cojones" (Hénault: 87). By the way, this same pun is also used by Ernest Hemingway.

In America we think nothing of giving a human name to an animal; however this is not done in some countries. 
It was Siberia for anyone who would name his dog Stalin. The Chinese were not allowed to use the sound "meow" for a cat when Chairman Mao was in power. People in Pakistan were incensed when the family of a U.S. diplomat named its dog Mohammed. (Slovenko: 281-282)

Likewise, many Spanish speakers name their boy children Jesus, but when this is translated into English Jesus the name takes on much stronger connotations than it had in the original Spanish.

Since nationality is such an important political issue, people often attempt to change their names to show different nationalities. In an article entitled "All About Names", Charlotte Montgomery reports a recent case involving a man who changed his name to a Hispanic one, claiming that people with Spanish-sounding names were getting grants, jobs and other advantages. But the U.S. Equal Employment Opportunity Commission decided,

"it would be abuse of Federal law to accept mere conversion to a Spanish surname as sufficient indication that the individual should be viewed as a minority." The man, incidentally, had changed his name from Robert E. Lee to Roberto Eduardo Leon. (Eschholz: 184)

\section{PARALINGUISTIC AND KINESIC CONSIDERATIONS}

In a book entitled Portraits of "The Whiteman" Keith Basso contrasts the paralinguistics of Americans with those of one tribe of American Indians.

Apaches talk to one another in a low, softly modulated tone. By comparison, they are forcefully struck by the Anglo speech which is comparatively rapid fire, loud and high pitched. Apaches find this quite amusing, saying that "Whiteman are angry even when they're friendly". (55)

Judy Kisselberg, a student at Arizona State University who lives on the Apache reservation, indicates that one game which Apaches play when they visit each other is to use the loud arrogant aggressive talk of the White Man. During this game the players all violate the Apache conversational traditions in exactly the same ways that White men violate these Apache traditions. They enjoy playing this game immensely, especially when there is a White man present, because he is totally unaware that a game is even being played.

\section{PRAGMATIC CONSIDERATIONS}

Whereas phonology, morphology, and syntax are language specific, pragmatics is more universal in scope; therefore translation at this level is often more effective. In The Innocents Abroad, Mark Twain tells about when he was in Yalta, where he "... danced an astonishing sort of dance an hour long ... with a very pretty girl, and we talked incessantly, and laughed exhaustingly, and neither one ever knew what the other was driving at. But it was splendid". (Nilsen, "Twain": 68)

While he was in Germany, Twain met an American student, whom he asked how he was getting along with his German. The student answered promptly:

"I am not getting along at all. I have worked at it hard for three level months, and all I have to show for it is one solitary German phrase - "Zwei glas" (two glasses of beer). He paused a moment, reflectively, then added with feeling, "But I've got that solid!" (Twain : 259)

In the Summer of 1984 we saw an enlistment advertisement for the Army in a bus in Montreal, Canada. The advertisement was in French, and painted a beautiful picture of what army life would be like. The linguistic message consisted of two words, "La diversité". However, a graffitist had made a change in the wording which affected the phonolo 
gy very slightly, but which completely reversed the semantics, for he had changed " $L a$ diversité" to "L'adversité". In bilingual Montreal, this change had the same effect for English readers as for French readers, for French "diversité", and "adversité", and English "diversity" and "adversity" have the same scansion, the same phonetic similarity, and the same semantic opposition in both English and French.

Indeed it is possible to use translation to redefine the world according to our perceptions and likings. Jo Thomas reports in the New York Times that the Soviet Union asked Oxford University Press if they [the Soviet Union] could define the words communism, socialism, and capitalism in the Soviet edition of the Oxford Student's Dictionary of Current English. After being given permission to make the changes, the Soviet version defined communism as "A theory revealing the historical necessity for the revolutionary replacement of capitalism by communism", and it defined socialism as "A social and economic system which is replacing capitalism". Capitalism on the other hand was defined as "An economic system based on private ownership of the means of production operated for private profit, and on the exploitation of man by man" (21). Victor Raskin tells a joke based on this last definition. "In the United States man exploits man; however in the Soviet Union, the reverse of this is true" (personal communication).

\section{AN INTERPLAY OF LEVELS}

In America there is an expression, "All work and no play makes Jack a dull boy". There is a Danish parody of this proverb, and it appears as part of a mural in the post office in Oswegatchie, Connecticut. The parody reads, "All vaerk and no play makes Nils a "rötegröte and flüde"" (Nilsen, "Parody": 158). The Danish parody is an improvement over the English original in a number of important respects. In the translation, but not in the original, there is a clash between the English and the Danish - a clash that causes tension, and leaves the reader uneasy because he no longer knows for sure which language is which. Is the word "vaerk", for example, a legitimate cognate of the English "work", or is it instead made up by the parodist? Another advantage of the translation is the detail. "A dull boy" does not have the same rhetorical density as does "a raspberry pudding". Not only is "raspberry pudding" metaphorical rather than literal, it is highly metaphorical - it is a farfetched and visually intriguing metaphor. The translation also scans better, and has assonance (both total and partial) that is lacking in the original. Although the proverb still has the universal applications that were present in the original, it has acquired an additional specificity that is lacking in the original, for this translatedand-improved proverb appears in a post office in Oswegatchie, Connecticut, a city-name which is itself a translation of an indigenous American Indian word, and which is poetic because it is exotic, and because it scans, and because it is not trite, as Boston, Massachusetts would be.

English has the proverb "You reap what you sow", but when this is translated into Mandarin Chinese there is again an improvement of rhetorical density, for it becomes, "zhong-gua-de-gua, zhong-dou-de-dou", which, when translated becomes "Grow melon get melon; grow bean get bean" (Chern: 8 ).

When a person speaks one language and then learns another language, many expressions in the new language replace the expressions in the original language, and the result is often humorous. Einar Haugen, in The Norwegian Language in America, comments on this strange intermeshing of languages:

In order to "maeka ei levving" they had to scratch about for a "jabb" which often meant that they had to join a "kru" (crew) of some kind and work under a "bas"... Many Norwegians found work in the "lomberkemper" which were located in the "peinri" (pineries)... As soon as they could, they acquired a "farm" which it never occurred to them to call "gard" as they 
had done in Norway. With the word came all its derivatives "farma" (to farm), "farmar" and "farming". If they could not afford to buy a farm they might "renta" and live as "rentarar" (renters), which entirely replaced the Norwegian "leiga" and "leilending". (76-77)

Edna Acosta-Belin comments on Haugen's quote above :

The examples illustrate the linguistic mechanisms generally used in the Americanization of immigrant languages. That is, the grammatical rules of the native language are applied to "borrowed" English words. (459)

\section{CONCLUSION}

It was Paul Anderson who said, "I have yet to see any problem, however complicated, which when you looked at it the right way did not become still more complicated" (Katz: 56). Humor is based on complication. In the first place, there are always two scripts, the natural one and the unexpected one. And there is a kind of an oppositional relationship between the two scripts. And there is frequently a key word or a trigger that operates to change the mind of the listener into a new mind set. And there has to be tension for something to be humorous. And there can't be too much tension, for that would change it from comedy to tragedy. And for humor to be effective, it must operate on more than a single level of analysis (phonological, syntactic, semantic, pragmatic, etc.). Now we are adding still another complication - that of translating the humor from one language and culture to another, with the added requirement that the translation must be better than the original. Here we have the proverbial dog not just dancing on its hind legs, but doing it extremely well.

In concluding, let me refer to Monty Python's "killer joke" to demonstrate the importance of humor and translation. The story goes that during World War II, one of the Monty Python actors creates a joke that is so funny that when he gets it written down and rereads it to himself he immediately laughs himself to death.

Hearing of this, the British government dispatches a team of translators to translate the joke into German so that it can be used as a weapon against the enemy. The translators are assigned only one word each because when one of them accidentally sees as few as two of the words of the joke they have to be hospitalized for several weeks. Now, once the joke is completely translated into German, it is given out to several British privates who don't understand German to read on the battlefield. (Hallmark : 147)

It was shortly after this that Germans surrendered.

\section{BIBLIOGRAPHY}

ACOSTA-BELIN, Edna (1982) : "'Spanglish' : A Case of Languages in Contact", Readings in Applied English Linguistics, Third Edition, Allen, Harold B., and Michael D. Linn (eds.), New York, Alfred A. Knopf, pp. $458-463$.

BAKER, Russell (1981): "A Tongue That Is Germane to the English Language", The Arizona Republic, 7 June, A7. BALDINGER, Kurt (1980) : Semantic Theory : Towards a Modern Semantics, New York, St. Martin's Press.

BASSO, Keith H. (1979): Portraits of "The Whiteman", Cambridge, England, Cambridge UP.

BENTZON, Th. (1872): "Les humoristes américains: I. Mark Twain", Revue des Deux mondes, C (July), pp. 313-335.

CHERN, Tzy Rong (1985): "Idioms and Second Language Learning", unpublished paper, Tempe, Arizona, Arizona State University.

DE KAY, Ormonde (1980): N' Heures Souris Rames, New York, Clarkson N. Potter.

DENNISON, Sandy (1980) : “Names", Wilmington News Journal, 18 October, pp. 1, 11.

ESCHHOLZ, Paul, Alfred ROSA, and Virginia CLARK, eds. (1982): Language Awareness, Third Edition, New York, St. Martin's Press.

ESPY, Willard R. (1982): A Children's Almanac of Words at Play, New York, Clarkson N. Potter/Crown. 
FLEXNER, Stuart Berg (1967) : "Preface : Amercian Slang", Dictionary of American Slang, Harold Wentworth and Stuart Berg Flexner (eds.), New York, Thomas Y. Crowell.

GRIFFITH, James S. (1983): "Bilingual Border Jokes", WHIMSY, 1 (April 1), p. 123.

HALLMARK, James D. (1984): "This Is a Joke", WHIMSY, 2 (April 1), pp. 144-148.

HAUGEN, Einar (1969): The Norwegian Language in America, Bloomington, Indiana, UP.

HÉNAULT, Marie (1983): "Linguistic Humor in William Gaddis's Recognitions", WHIMSY, 1 (April 1), pp. 85-87.

HULME, John (1981) : Mörder Guss Reims : The Gustav Leberwurst Manuscript, New York, Clarkson N. Potter.

JONES, Horace Perry (1983-1984): "Southem Editorial Humor and the Crimean War", Studies in American Humor, 2:3 (Winter), pp. 171-184.

KATZ, Jerrold J. (1972) : Semantic Theory, New York, Harper and Row,

LEDERER, Richard (1986) : "Looking at Language", Concord Monitor, 27, May.

LEDERER, Richard : "Lost in Translation", National Shorthand Reporter (January), 40, 42.

LEGMAN, Gershon (1968): No Laughing Matter : An Analysis of Sexual Humor, Vol. 1, Bloomington, Indiana, UP.

LEHMANN, Winfred P. (1983) : Language : An Introduction, New York, Random.

LONG, E. Hudson (1957): Mark Twain Handbook, New York, Hendricks House.

NILSEN, Don L.F. (1981): "Bilingual and Bidialectal Language Play", Rocky Mountain Review of Language and Literature, $35: 2$ (Spring), pp. 128-137.

NILSEN, Don L.F. (1977): "Kabul Sign Language: A Historical Perspective", Afghanistan Journal, $4: 4$, pp. $149-154$.

NILSEN, Don L.F. (1982): “Mark Twain's Coping Techniques", in The Study of Humor, Harvey Mindess and Joy Turek (eds.), Venice, California, Antioch University.

NILSEN, Don L.F. (1985): "Rötegröte Med Fiüde: The Extent of Parody in American Culture", WHIMSY, 3 (April 1), pp. 158-160.

NILSEN, Don L.F. and Sajida KAMAL (1969): "Some Metaphors in Kabul Dari", Adab, 16, pp. 7-14.

ROSS, Leonard Q. (1968): "The Education of $H^{*} Y^{*} M^{*} A^{*} N K^{*} A * P^{*} L^{*} A * N$, New York, Harcourt, Brace.

ROSTEN, Leo (1966): "Wallop Yon Horse with a Parachute", Look, 30, p. 16.

SLOVENKO, Ralph (1983) : "The Human/Companion Animal Bond and the Anthropomorphizing and Naming of Pets", Medicine and Law, 2, pp. 277-283.

SOMMER-SAMAI, Valerie (1985): "Japanese Imagery in the Spoken Language: Seen Through Everyday Metaphors", unpublished paper, Tempe, Arizona, Arizona SU.

THOMAS, Jo (1985): "Russians Redefine Words in Oxford Student Dictionary", New York Times Arts/Entertainment, 9 April, p. 21.

TWAIN, Mark (1880) : A Tramp Abroad, New York, Harper and Row.

VAN ROOTEN, Luis d'Antin (1697): Mots d'Heures Gousses, Rames : the d'Antin Manuscript, New York, Penguin.

WATTS, Pam (1985) : "Persian Metaphorical Language - Some Examples from an Iranian Film", unpublished paper, Tempe, Arizona, Arizona SU. 